\title{
Neuronal and Glial Prostaglandin D Synthase Isozymes in Chick Dorsal Root Ganglia: A Light and Electron Microscopic Immunocytochemical Study
}

\author{
Marie-Françoise Vesin, ${ }^{1}$ Yoshihiro Urade ${ }^{2}$, Osamu Hayaishi, ${ }^{2}$ and Bernard Droz ${ }^{1}$ \\ IInstitut d'Histologie et d'Embryologie, Faculté de Médecine, Université de Lausanne, 1005 Lausanne, Switzerland and \\ ${ }^{2}$ Osaka Bioscience Institute, 6-2-4 Furuedai, Suita-Shi, Osaka 565, Japan
}

Homogenates of chick dorsal root ganglia (DRG) and in vitro cultures of DRG neurons are known to synthesize prostaglandin (PG) $D_{2}$. To specify the PGD synthase isozymes controlling $P G D_{2}$ synthesis in DRG and to identify the DRG cells responsible for this synthesis, we applied polycional antibodies raised against rat brain or rat spleen $P G D$ synthase isozymes to vibratome or cryostat slices of DRG previously fixed with a formaldehyde-lysine-periodate mixture and permeabilized with Triton X-100. The immunoreactivity indicating rat spleen PGD synthase, a glutathione (GSH)-requiring enzyme, was located in satellite cells encompassing particular large neurons of class $A$ and in Schwann cells myelinating and enwrapping their initial axonal segments. In contrast, the immunoreactivity of rat brain PGD synthase, a GSH-independent enzyme, was restricted to particular ganglion cell perikarya: $33 \%$ of the DRG neurons were immunostained for rat brain PGD synthase, including $2 \%$ of large class A neurons and $\mathbf{4 0} \%$ of small class $B$ neurons. Only $3.3 \%$ of rat brain PGD synthase-immunoreactive small $B$ neurons coexpressed substance $P$, indicating that the immunoreactive neurons belong to the $B_{1}$ subclass. By electron microscopy, 71 of 72 immunoreactive DRG cells were identified as small $B$ neurons of the $B$, subclass, and 71 of 77 $B_{1}$ neurons were immunoreactive for rat brain $P G D$ synthase. These results demonstrate that $P G D_{2}$ formation in $D R G$ is regulated by two isozymes: the GSH-requiring isozyme located in satellite and Schwann cells and the GSH-independent isozyme-confined to small $B_{1}$ neurons.

IKey words: prostaglandin $D_{2}$, prostaglandin $D$ synthase, substance $P$, primary sensory neurons, satellite cells, Schwann cells, dorsal root ganglia]

$\mathrm{PGD}_{2}$ is one of the major PGs synthesized in the CNS of mammals (Abdel-Halim and Änggård, 1979; Shimizu et al., 1979; Gerozissis et al., 1983; Ogorochi et al., 1984). $\mathrm{PGD}_{2}$ is involved

Received Feb. 3, 1994; revised June 20, 1994; accepted June 29, 1994

We thank Dr. J.-Y. Couraud for providing substance P antibody and Drs. S. S. Kantha and N. Eguchi for critical reading of the manuscript; we also express our gratitude to Mrs. C. Pfülg for her skillful technical assistance, to Mrs. A. Uygur and Mr. P.-A. Milliquet for illustrations, and to Mrs. M. Blanc and M. Pasquier for typing the manuscript. This work was supported by a grant $(3.397-86)$ from the Swiss National Foundation.

Correspondence should be addressed to Dr. M.-F. Vesin, Institut d'Histologie et d'Embryologie, Faculté de Médecine, Rue du Bugnon 9, 1005 Lausanne, Switzerland.

Copyright (C) 1995 Society for Neuroscience $0270-6474 / 95 / 150470-07 \$ 05.00 / 0$ in modulation of important neural functions such as thermoregulation, sleep, neurohormone release, and nociception (for reviews, see Davies et al., 1984; Barkai and Bazan, 1989; Ito et al., 1989; Shimizu and Wolfe, 1990; Hayaishi, 1991). Recent studies have demonstrated that $\mathrm{PGD}_{2}$ is also synthesized in the PNS, especially in the dorsal root ganglia (DRG) and to a lesser extent in the sciatic nerve of chickens (Vesin and Droz, 1991; Vesin et al., 1991). In DRG, the existence of PGD synthase in DRG neurons could be indirectly surmised since PGD synthesis occurs in chick embryo DRG at an early developmental stage when DRG contain mostly maturing neurons (Vesin and Droz, 1991). Furthermore, neuron-enriched DRG cell cultures more actively metabolize arachidonate into $\mathrm{PGD}_{2}$ than non-neuronal cell cultures such as Schwann cells (Vesin et al., 1991). Thus, DRG neurons are the most important, but not the sole, source of $\mathrm{PGD}_{2}$. In fact the problem of the cellular origin of $\mathrm{PGD}_{2}$ is more complicated since DRG neurons are composed of two main classes: large and light A neurons and small and dark B neurons. Both classes are subdivided into two subclasses based on ultrastructural and immunocytochemical criteria (Philippe and Droz, 1988). Peripheral glial cells are also separated into two distinct groups: satellite cells and Schwann cells (Pannese, 1974). The situation is even rendered more complex because $\mathrm{PGD}_{2}$ is synthesized by at least three distinct enzymes (Ujihara et al., 1988a): (1) PGD synthase of the "spleen" type, a GSHrequiring enzyme (Christ-Hazelhof and Nugteren, 1979; Urade et al., 1987a), present in spleen, thymus, bone marrow, intestine, skin, and stomach (Ujihara et al, 1988c; Urade et al., 1989b, 1990a); (2) PGD synthase of the "brain" type, a GSH-independent enzyme (Urade et al., 1985), present in brain, spinal cord, and epididymis (Urade et al., 1987b, 1989a, 1993); and (3) the great variety of GSH S-transferases that convert $\mathrm{PGH}_{2}$ into various PGs including $\mathrm{PGD}_{2}$ (Ujihara et al., 1988b).

In order to specify and localize the type of PGD synthase(s) in chick DRG, we undertook immunocytochemical detection of PGD synthases by using rabbit IgG raised against PGD synthase of the rat brain or the rat spleen type. The results clarify the presence of these two PGD synthase isozymes in distinct populations of chick DRG cells: (1) the "spleen" type of the enzyme confined to particular satellite cells surrounding large A neurons and to Schwann cells encompassing the initial segment of the axon, and (2) the "brain" type of the enzyme located in small B primary sensory neurons and particularly concentrated in the $B_{1}$ neurons, the latter of which rarely coexpress substance $P$. 


\section{Materials and Methods}

Goat anti-rabbit $\mathrm{IgG}$ and rabbit peroxidase-antiperoxidase complex were supplied by Bio-Science Products A.G. (Emmembrücke, Switzerland). Rabbit anti-mouse IgG and mouse peroxidase-antiperoxidase were from Dakopatts (Glostrup, Denmark). Diaminobenzidine tetrachloride (DAB) was purchased from Fluka (Buchs, Switzerland); Reichert Jung Einbettmedium, from Cambridge Instruments GmbH (Nubloch, Germany); and the liquid scintillation counting solution Kontrogel from Kontron (Zürich, Switzerland). Analytical reagents and all other solvents used were products of Merck (Darmstadt, Germany).

\section{Experimental procedure}

Tissue fuxation and sectioning. Anesthetized $12 \mathrm{~d}$ old chicken were perfused intracardially first for $2 \mathrm{~min}$ with $0.1 \mathrm{M}$ sodium phosphate $\mathrm{pH}$ 7.4 , adjusted to $360 \mathrm{mOsm}$ with $\mathrm{NaCl}$ (PBS) and then for 20 min with the following fixative mixture: $0.22 \%$ periodate, $0.4 \%$ lysine, and $4 \%$ formaldehyde in PBS (McLean and Nakane, 1974). The DRG were rapidly excised, decapsulated, and postfixed for $2 \mathrm{hr}$ at $4^{\circ} \mathrm{C}$ in the same fixative solution.

After fixation, tissues were extensively washed with PBS, and either directly sectioned as $20 \mu \mathrm{m}$ thick slices with a vibratome or cryoprotected with sucrose gradient in PBS ( $1 \mathrm{hr}$ in 5\% sucrose, $2 \mathrm{hr}$ in $15 \%$ sucrose, and finally $24 \mathrm{hr}$ in $30 \%$ sucrose) and cut at a $10 \mu \mathrm{m}$ thickness with a cryostat.

Immunocytochemical detection of $P G D$ synthases. Polyclonal antiserum against PGD synthase of the rat brain type or rat spleen type was elicited in rabbits by immunization with enzymes purified to apparent homogeneity, and the IgG fractions were isolated (Urade et al., 1985; Urade et al., 1987a). The specificity of the polyclonal antibodies raised against the rat brain or rat spleen PGD synthase isozyme was characterized by Ouchterlony double immunodiffusion, immunoblot, and immunotitration tests (Urade et al., 1985, 1987a) prior to use in the present study, and the two antisera were demonstrated to show no cross-reaction.

The localization of the PGD synthases was investigated by the peroxidase-antiperoxidasc mcthod of Sternberger (1979). Vibratome slices were incubated for $10 \mathrm{~min}$ at $20^{\circ} \mathrm{C}$ with $5 \% \mathrm{H}_{2} \mathrm{O}_{2}$ in PBS to quench endogenous peroxidase. After three $15 \mathrm{~min}$ washes, the slices were preincubated for $45 \mathrm{~min}$ with 3\% normal goat serum and incubated for 24 hr at $4^{\circ} \mathrm{C}$ with rabbit IgG raised against rat brain or rat spleen PGD synthase $(1: 1000)$. The rinsed slices were subsequently treated with goat anti-rabbit IgG (dilution, 1:40) for $45 \mathrm{~min}$ followed by peroxidaseantiperoxidase complex (dilution, 1:100) for $30 \mathrm{~min}$. All solutions were diluted in PBS containing $0.25 \%$ Triton X-100 (except when indicated). After repeated washes over a $45 \mathrm{~min}$ period, the peroxidase activity was revealed by incubating the slices for $5 \mathrm{~min}$ in $50 \mathrm{~mm}$ Tris $\mathrm{HCl}(\mathrm{pH}$ 7.4) containing $0.03 \% \mathrm{DAB}$ and $0.01 \% \mathrm{H}_{2} \mathrm{O}_{2}$. The slices were finally mounted in glycerol for light microscopy.

In the immunocytochemical controls, antibodies specific for PGD synthase werc replaced by normal rabbit serum or the primary antibodies preabsorbed with the cytosolic fraction of DRG, which is known to contain PGD synthase activity (Vesin and Droz, 1991). In another control, normal goat serum was employed in place of the goat antirabbit IgG.

Colocalization of $P G D$ synthase and substance $P$. The colocalization of PGD synthase and substance $P$ was investigated on adjacent cryostat slices collected on gelatin- coated slides. The detection of PGD synthase was performed as described above. The presence of substance $\mathbf{P}$ was visualized by the same procedure except that slices were sequentially treated with 1:500 dilution of substance $P$ monoclonal antibody ( $\mathrm{mAB}$ SP 31) kindly provided by Dr. J. Y. Couraud (Saclay, France), rabbit anti-mouse IgG (1:40), and mouse peroxidase-antiperoxidase complex (1:100). For a control experiment, slices were treated with nonimmune ascitcs fluid (1:500) instead of the primary antibody.

Electron microscopy. Vibratome slices were immunostained as described above except that (1) the incubation time to permeabilize the tissue with Triton X-100 was shortened to $30 \mathrm{~min}$, and (2) the slices were postfixed for $30 \mathrm{~min}$ with $1 \%$ glutaraldehyde in PBS and successively treated for $2 \mathrm{~min}$ with $1 \%$ gelatin and for $15 \mathrm{~min}$ with $30 \mathrm{~mm}$ lysine $(\mathrm{pH} \mathrm{10)}$ to block free aldehyde groups prior to the DAB reaction. After the DAB procedure, the slices were postfixed for $2 \mathrm{hr}$ at room temperature in a $1: 1(\mathrm{v} / \mathrm{v})$ solution of $2 \%$ aqueous $0 \mathrm{~s}_{4}$ and $3 \%$ aqueous K-ferrocyanide (Karnowski, 1971), dehydrated through graded ethanol solutions, and finally flat-embedded in Epon (Reymond and Pickett-
Table 1. Quantitative evaluation of large $A$ and small $B$ neurons immunostained with anti-rat brain PGD synthase antibody

\begin{tabular}{|c|c|c|c|c|}
\hline \multirow[b]{2}{*}{$\begin{array}{l}\text { Experi- } \\
\text { ment }\end{array}$} & \multicolumn{2}{|c|}{ Large A neurons } & \multicolumn{2}{|c|}{ Small B neurons } \\
\hline & $\begin{array}{l}\text { Immuno- } \\
\text { reactive } \\
\text { cells/total } \\
\text { A cells }\end{array}$ & $(\%)$ & $\begin{array}{l}\text { Immuno- } \\
\text { reactive } \\
\text { cells/total } \\
\text { B cells }\end{array}$ & $(\%)$ \\
\hline 1 & $1 / 57$ & $(1.8)$ & $45 / 90$ & $(50.0)$ \\
\hline 2 & $1 / 48$ & $(2.1)$ & $74 / 206$ & $(35.9)$ \\
\hline 3 & $0 / 41$ & $(0)$ & $89 / 210$ & $(42.4)$ \\
\hline 4 & $1 / 45$ & $(2.2)$ & $72 / 233$ & $(30.9)$ \\
\hline 5 & $2 / 28$ & $(7.1)$ & $105 / 257$ & $(40.9)$ \\
\hline 6 & $0 / 23$ & $(0)$ & $156 / 414$ & $(37.7)$ \\
\hline Total & $5 / 242$ & $(2.2 \pm 1.1)^{a}$ & $541 / 1410$ & $(39.6 \pm 2.6)^{a}$ \\
\hline
\end{tabular}

The cells in which the nucleus was present were counted and sized by measuring the largest diameter. These cells divided into two groups: (1) small B neurons with a diameter of $20-40 \mu \mathrm{m}$ and (2) large A neurons with a diameter of $50-80 \mu \mathrm{m}$. The number of rat brain PGD synthase-immunoreactive cells was determined for each subpopulation in six different experiments.

a Values are means $\pm \mathrm{SE}$.

Heaps, 1983). Serial $1 \mu \mathrm{m}$ and $0.1 \mu \mathrm{m}$ thick sections were obtained. The superficial $1 \mu \mathrm{m}$ thick sections were used to locate the immunoreactive cells under the light microscope. The adjacent $0.1 \mu \mathrm{m}$ thick sections were counterstained for $5 \mathrm{~min}$ with lead citrate (Reynolds, 1963) and then examined with a Zeiss EM10C electron microscope.

\section{Results}

Light microscopic distribution of PGD synthase immunoreactivities assessed with antibodies against the rat brain and rat spleen enzymes

After treatment of vibratome slices of chicken DRG with antibodies raised against rat brain PGD synthase, positive immunostaining was first detected with a concentration of antibody of $1 \mu \mathrm{g} / \mathrm{ml}$, and the intensity increased up to $10 \mu \mathrm{g} / \mathrm{ml}$ while the background remained relatively low at this concentration (Fig. $1 A)$ and corresponded to that observed in control slices incubaled with preimmune rabbit serum (Fig. $1 G$ ) or the preabsorbed antibody (Fig. $1 G, H$ ). The specific immunoreaction was concentrated in perikarya of small $\mathrm{B}$ ganglion cells mainly confined to the mediodorsal region of the DRG (Fig. $1 A$ ). A few thin axons emerging from strongly immunostained ganglion cell bodies disclosed a weak immunoreactivity (Fig. $1 A$ and $C$ ).

A quantitative analysis of a total of 1652 DRG neurons (Table 1) showed that $33.0 \%$ of the neurons (546 cells) were immunostained in which $32.7 \%$ (541 cells) corresponded to small B neurons and $0.3 \%$ ( 5 cells) were large A neurons. The immunoreactivity for rat brain PGD synthase was observed in about $2 \%$ ( 5 of 242 cells) and $40 \%$ (541 of 1410 cells) of the identified large A and small B neurons, respectively. The immunostained small B cells displayed granular peroxidase precipitates distributed homogeneously throughout the perikaryon or aggregated in clumps (Fig. $1 B$ ). The immunoreactive ganglion cells were generally grouped together. The rarc immunostained large A cells showed granular and scattered immunoprecipitates.

When the immunocytochemical detection of PGD synthase in DRG was assayed with $1-20 \mu \mathrm{g} / \mathrm{ml}$ antibody raised against rat spleen $\mathrm{PGD}$ synthase, the intense, specific immunostaining was observed in satellite cells surrounding particular ganglion cell bodies of large class $A$ neurons and in the cytoplasm of Schwann cells ensheathing the initial segment of their large myelinated axons (Fig. $1 D-F$ ). In contrast, the perikaryon of $\mathrm{DRG}$ 

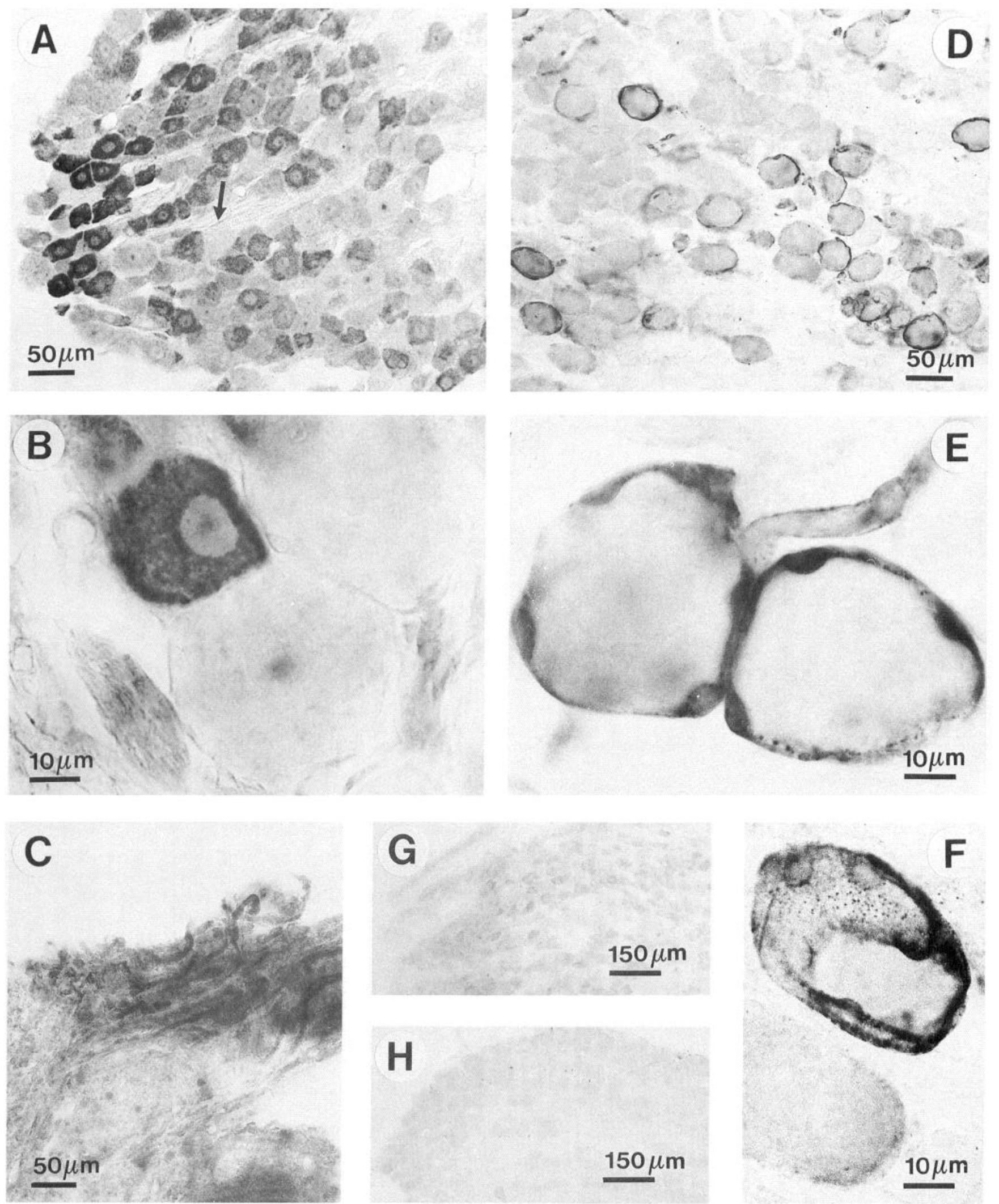

Figure 1. Immunocytochemical localization of PGD synthase isozymes in chick DRG. Vibratome sections of the DRG were immunostained with anti-rat brain PGD synthase antibodies $(A-C)$, anti-rat spleen PGD synthase antibodies $(D-F)$, nonimmunized rabbit serum $(G)$, and anti-rat brain PGD synthase antibodies preabsorbed with the cytosolic fraction of chick DRG $(H)$. $A$, The immunoreactivity for rat brain PGD synthase is localized in small B neurons in the mediodorsal part of DRG. The arrow shows thin unmyelinated axons exhibiting discrete immunoreactivity. $B$, At higher magnification, the immunodeposits appear aggregated in clumps in the cell body of a small B neuron but are not detected in two neighboring large A neurons. $C$, Immunoreactivity for PGD synthase of the brain type is also observed in thin axons issuing from the dorsal root 
cells encompassed by immunostained satellite cells displayed either a lack of immunoreactivity or slight and irregular immunostaining that could have been due to the superimposed immunostained cytoplasm of satellite cells (Fig. $1 E, F$ ).

\section{Dual detection of PGD synthase of the brain type and substance $P$ in adjacent cryostat sections}

In cryostat sections of DRG treated with anti-rat brain PGD synthase IgG, the immunoreaction was observed principally in small dark B neurons (Fig. $2 A$ ), displaying the same pattern as in the vibratome slices (Fig. $1 A$ ). When the sections were incubated with anti-substance $\mathrm{P}$ antibody, positive immunostaining was mostly observed in the perinuclear zone corresponding to the Golgi apparatus of small dark B cells (Fig. $2 B$ ). Comparison of adjacent sections alternatively treated with antibodies against rat brain $\mathrm{PGD}$ synthase and substance $\mathrm{P}$ indicated that both immunoreactivities were localized to the class B neurons yet rarely coexisted in the same cell (Fig. $2 A, B$ ). A quantitative analysis of 250 small dark $B$ neurons revealed that $20.1 \%$ were negative to both antibodies, $30.0 \%$ were rat brain $\mathrm{PGD}$ synthase immunopositive, $46.6 \%$ were substance $\mathrm{P}$ immunopositive, and only $3.3 \%$ displayed both immunoreactivities.

\section{Electron microscopic identification of DRG neurons immunostained with anti-rat brain $P G D$ synthase antibodies.}

In $20 \mu \mathrm{m}$ thick vibratome slices that were processed for later electron microscopy, small B neurons showed intense immunoreactivity for rat brain PGD synthase among nonimmunostained DRG cells. After Epon embedding of such slices and sectioning, the most superficial $1 \mu \mathrm{m}$ thick section still displayed a clear immunoreaction in particular small $\mathrm{B}$ ganglion cell bodies (Fig. $3 A$ ) that were immunopositive. In the third to fourth subsequent $1 \mu \mathrm{m}$ thick sections, the immunopositive neurons gradually lost their immunostaining (Fig. $3 B$ ) so that the further $0.1 \mu \mathrm{m}$ thick sections failed to show any more immunoprecipitates in the immunopositive ganglion cell bodies (Fig. 3C). The ultrastructural features of the rat brain PGD synthase bearing nerve cell bodies remained better preserved in the deep sections than in the superficial ones. We therefore used the deep thin sections to analyze the cytological criteria characterizing the neurons identified as being rat brain PGD synthase immunoreactive. Among 72 PGD synthase-immunoreactive DRG cells, 71 cells shared ultrastructural features specifically ascribed to small B neurons of the $B_{1}$ subclass (Philippe and Droz, 1988): a zonal organization of the organelles in the perikaryon, a parallel arrangement of the rough endoplasmic reticulum in the outer zone of the cytoplasm, straight stacks of Golgi saccules in the medial zone, and shorter Golgi saccules intermingled with mitochondria predominating in the inner perinuclear zone (Fig. $3 D$ ). On the other hand, 71 out of 77 small $B$ neurons of the $B_{1}$ subclass were immunoreactive for rat brain $\mathrm{PGD}$ synthase.

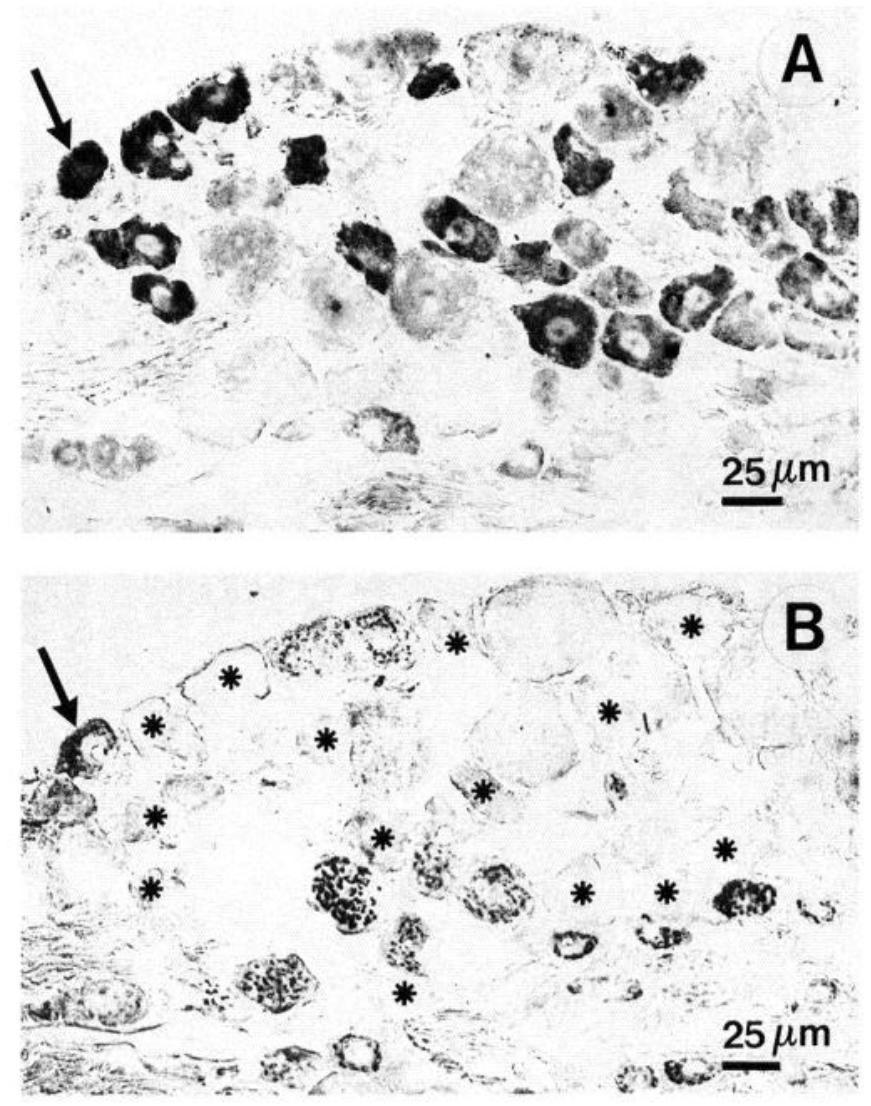

Figure 2. Distinct localization of the immunoreactivities for rat brain PGD synthase and substance $P$ in small B neurons of chick DRG. Adjacent cryosections were immunostained with antibodies against rat brain PGD synthase $(A)$ and substance $\mathrm{P}(B)$. Small $\mathrm{B}$ neurons possessing the immunoreactivity for rat brain PGD synthase are marked by asterisks in $B$, most of which are devoid of the immunoreactivity for substance P. Arrows in $A$ and $B$ point to one of the rare small B neuron exhibiting immunoreactivities to both rat brain PGD synthase and substance $\mathrm{P}$.

\section{Discussion}

'Rat brain"-type PGD synthase: a neuronal enzyme in chicken DRG

The immunostaining obtained with antibodies raised against rat brain $\mathrm{PGD}$ synthase shows that the immunoreactivity for this isozyme in chick DRG is restricted to a subpopulation of small-sized neurons of class B preferentially located in the mediodorsal region. These rat brain PGD synthase-positive neurons display ultrastructural traits ascribed to subclass $B_{1}$ neurons that express calbindin D-28k (Philippe and Droz, 1988) and rarely (1-2\%) coexpress substance P (Duc et al., 1991). The functional activity of the neuronal rat brain PGD synthase in the DRG was previously demonstrated in cultures of DRG neurons free of non-neuronal cells: in the absence of exogenous

\footnotetext{
and entering the dorsal horn of the spinal cord. D, Immunoreactivity for rat spleen PGD synthase encompasses most of the cell bodies of large A neurons in the lateroventral part of DRG. E, At higher magnification, the immunoreactivity for PGD synthase of the spleen type is localized to satellite cells surrounding large A neurons and to Schwann cells enwrapping the initial segment of the axon. The diffuse immunostaining occasionally detected in large A neurons is due to the superimposed immunoreactive satellite cell (see $F$ ). $F$, In a tangential section of the ganglion cells, the immunoreactivity is restricted to the satellite cells covering the neuronal cell bodies but does not extend to the neuronal perikaryon. $G$ and $H$, No significant immunostaining is observed with nonimmunized rabbit serum $(G)$ or the absorbed anti-rat brain PGD synthase antibodies $(H)$.
} 

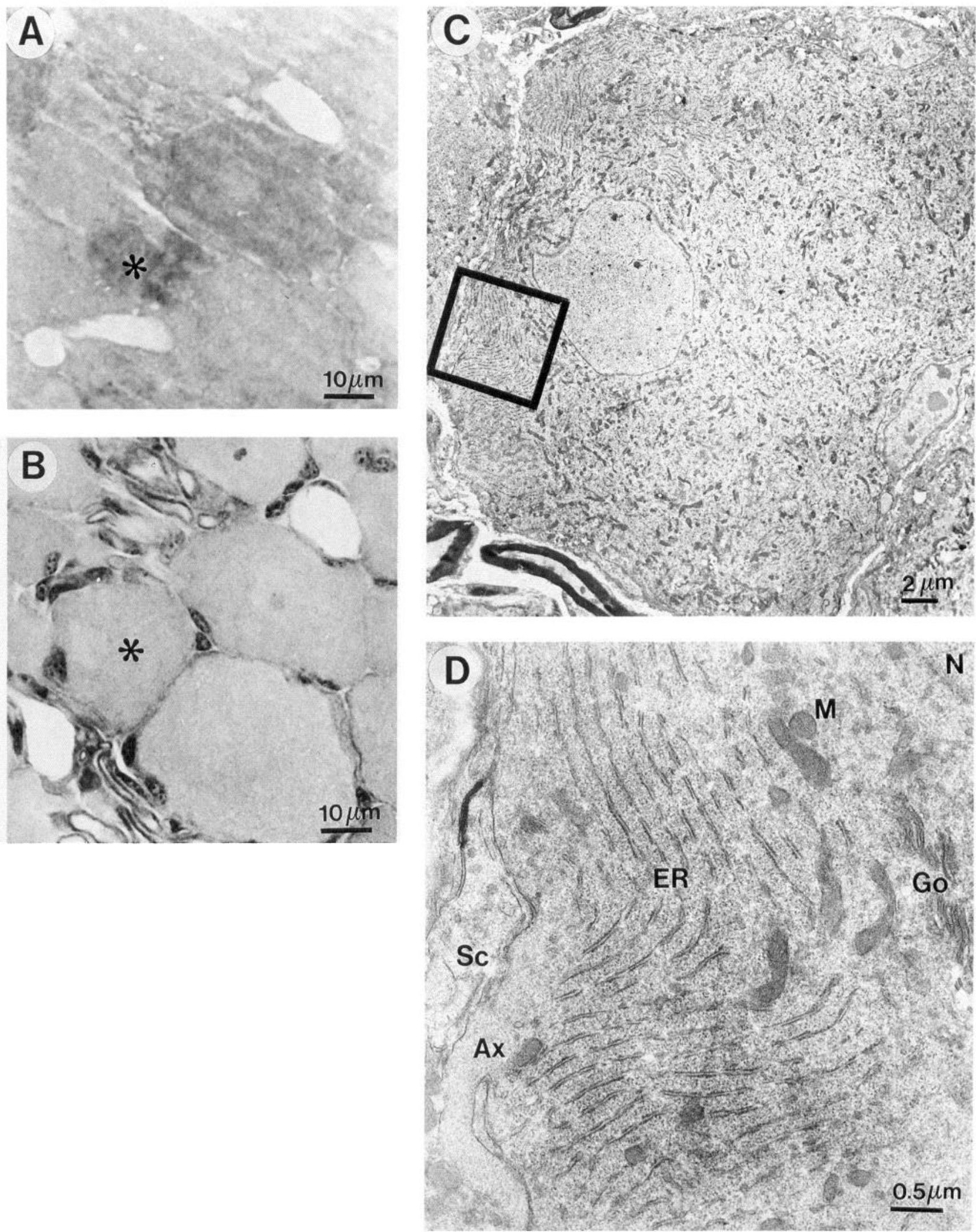

Figure 3. Electron microscopic identification of small B neurons possessing immunoreactivity for rat brain PGD synthase. A, After Eponembedding, the immunostained neurons are seen (asterisk) in the most superficial $1 \mu \mathrm{m}$ thick section observed under the light microscope. $B$, In the fourth $1 \mu \mathrm{m}$ thick section, the immunoreaction product is absent from the positive neuron. $C$ and $D$ (an enlargement of the area shown by the square in $C$ ), The electron micrographs of the adjacent thin section revealed that the ganglion cell (asterisks in $A$ and $B$ ) previously confirmed to be immunopositive has the ultrastructural traits characteristic of primary sensory neurons of the subtype $B_{1}$ : parallel cisternae of rough endoplasmic reticulum $(E R)$ in the outer zone of the cytoplasm and short Golgi saccules $(G o)$ intermingled with mitochondria $(M)$ in the inner perinuclear zone. $N$, nucleus; $A x$, axon; $S c$, satellite cell. 
GSH, neuron-enriched DRG cell cultures synthesized $\mathrm{PGD}_{2}$ more actively than $\mathrm{PGE}_{2}$ (Vesin et al., 1991). The poor immunostaining of the thin axons issuing from the rat brain PGD synthase-positive perikarya is probably due to the limited sensitivity of the immunodetection procedure, since a reinforcement of the immunoreactivity is observed in particular axons of the dorsal roots entering the spinal cord and crossing the neuropil of the layers 2 and 3 of the dorsal horn (Fig. 1C). Such a distribution of the isozyme suggests that rat brain PGD synthase is synthesized, like other proteins, in the neuronal perikaryon, loosely bound to membrane (Urade et al., 1987b), and transported to preterminal axons of the spinal central branch in which the isozyme accumulates (Fig. 1C). A similar process would occur in the distal branches innervating peripheral targets.

Since PGs act in the vicinity of their sites of formation according to an autocrine or paracrine process, DRG neurons of the subclass $B_{1}$ that possess PGD synthase of the brain type could release $\mathrm{PGD}_{2}$ from their perikarya or axon preterminals. Unfortunately, little is known about the distribution of $\mathrm{PGD}_{2}$ receptors except in synaptosomes (Shimizu et al., 1982). It cannot be excluded that $\mathrm{PGD}_{2}$ released from the ganglion cell bodies could act on neuronal autoreceptors or on satellite cell receptors. More probably $\mathrm{PGD}_{2}$ of neuronal origin would be involved in cell-cell communication at the level of the preterminal part of the axons. In the case of the hyperalgesia produced by $\mathrm{PGD}_{2}$, neuronal $\mathrm{PGD}_{2}$ released in the vicinity of nociceptive C-fibers could inhibit the $\mathrm{Ca}^{2+}$-activated- $\mathrm{K}^{+}$conductance and prevent the self-limitation of the firing rate of C-fibers (Taylor and Pierau, 1991). Another possibility is that neuronal $\mathrm{PGD}_{2}$ released in the neuropil of the layers 2 and 3 would cause an increase in substance $\mathrm{P}$ release to enhance nociception (Vasko et al., 1989; Uda et al., 1990).

"Rat spleen" type PGD synthase: a satellite and Schwann cell enzyme in chicken $D R G$

PGD synthase of the spleen type was not detected in DRG neurons but localized to the glial cells such as satellite cells and Schwann cells that enwrap the cell bodies and myelinate the initial axonal segment of particular large A neurons, respectively. This peculiar distribution of the isozyme in close contact with a subclass of ganglion cell bodies suggests that $\mathrm{PGD}_{2}$ synthesized in and released from satellite and/or proximal Schwann cells interacts with $\mathrm{PGD}_{2}$ receptors of the adjacent DRG neurons. Unfortunately, binding experiments with ${ }^{3} \mathrm{H}$-labeled $\mathrm{PGD}_{2}$ failed to show a significant and specific radioautographic localization of the ligand in any neuronal subpopulation of the chick DRG (as described above). Another possibility is that a byproduct of $\mathrm{PGD}_{2}$ metabolism, such as $\Delta^{12}$-PG. ${ }_{2}$, would be transferred from adjacent peripheral glia cells to the ganglion cell nucleus and be bound to chromatin to control gene expression of particular proteins (Ito et al., 1989). An alternative candidate would be $9 \alpha, 11 \beta-\mathrm{PGF}_{2}$ produced by $\mathrm{PGD}_{2} 11$-ketoreductase. This enzyme is widely distributed in various bovine tissues (Urade et al., 1990b) and also in the human cerebral cortex (Wolfe et al., 1989), although the neural function of $9 \alpha, 11 \beta-$ $\mathrm{PGF}_{2}$ remains unclear.

Thus, contrary to the CNS, which contains the rat brain PGD synthase predominantly, and in contrast to the spleen, thymus, bone marrow, intestine, skin, and stomach, which contain the rat spleen PGD synthase only, DRG display both isozymes: the rat brain PGD synthase in a subset of small class $B$ neurons identified as $\mathrm{B}_{1}$ and the rat spleen PGD synthase in peripheral glia enwrapping a subset of large class A ganglion cell bodies. The distinct cellular distribution of the two isozymes as well as their distinctly different GSH requirement and $K_{m}$ for the $\mathrm{PGH}_{2}$ substrate (Urade et al., 1987a) suggests that the regulation of the $\mathrm{PGD}_{2}$ synthesis by the two isozymes is different.

\section{References}

Abdel-Halim MS, Änggård E (1979) Regional and species differences in endogenous prostaglandin biosynthesis by brain homogenates. Prostaglandins 17:411-418.

Barkai AI, Bazan NG (1989) Arachidonic acid metabolism in the nervous system physiological and pathological significance. Ann NY Acad Sci 559:1-504.

Christ-Hazelhof E, Nugteren OH (1979) Purification and characterization of prostaglandin endoperoxide D-isomerase, a cytoplasmic, glutathione-requiring enzyme. Biochim Biophys Acta 572:43-51.

Davies P, Bailey PJ, Goldenberg MM (1984) The role of arachidonic acid oxygenation products in pain and inflammation. Annu Rev Immunol 2:335-357.

Duc C, Barakat-Walter I, Droz B (1991) Substance P and calbindin D-28k-immunoreactivity in primary sensory neurons of chick embryos: differential neuronal birthdates and transient co-localization, Biol Cell 71:73-80.

Gerozissis K, Saavedra JM, Dray F (1983) Prostanoid profile in specific brain areas, pituitary and pineal gland of the male rat. Influence of experimental conditions. Brain Res 279:133-139.

Hayaishi $O$ (1991) Molecular mechanisms of sleep-wake regulation: roles of prostaglandin $\mathrm{D}_{2}$ and $\mathrm{E}_{2}$. FASEB J 5:2575-2581.

Ito $S$, Narumiya $S$, Hayaishi O (1989) Prostaglandin $\mathrm{D}_{2}:$ a biochemical perspective. Prostagland Leuk Essent Fatty Acid 37:219-234.

Karnowski MJ (1971) Use of ferrocyanide-reduced osmium tetroxide in electron microscopy. Proc Am Soc Cell Biol 146.

McLean IW, Nakane PK (1974) Periodate-lysine-paraformaldehyde fixative a new fixative for immunoelectron microscopy. J Histochem Cytochem 22:1077-1083.

Ogorochi T, Narumiya S, Mizumo N, Yamashita K, Miyazaki H, Hayaishi $O$ (1984) Regional distribution of prostaglandins $D_{2}, E_{2}$ and $F_{2 \alpha}$ and related enzymes in postmortem human brain. $J$ Neurochem 43:71-82.

Pannese E (1974) The histogenesis of the spinal ganglia. In: Advances in anatomy, embryology and cell biology, Vol 47 (Brodal A, Hild W, Van Limborgh J, Ortmann R, Schiebler TH, Töndury G, Wolff E, eds), pp 3-97. Berlin: Springer.

Philippe E, Droz B (1988) Calbindin D-28k-immunoreactive neurons in chick dorsal root ganglion: ontogenesis and cytological characteristics of the immunoreactive sensory neurons. Neuroscience 26:215224.

Reymond OL, Pickett-Heaps JD(1983) A routine flat embedding method for electron microscopy of microorganisms allowing selection and precisely orientated selectioning of single cells by light microscopy. J Microse 130:79-84.

Reynolds ES (1963) The use of lead citrate at high $\mathrm{pH}$ as an electronopaque stain in electron microscopy. J Cell Biol 17:208-212.

Shimizu T, Wolfe L (1990) Arachidonic acid cascade and signal transduction. J Neurochem 55:1-15.

Shimizu T, Mizuno N, Amano T, Hayaishi O (1979) Prostaglandin $\mathrm{D}_{2}$, a neuromodulator. Proc Natl Acad Sci USA 76:6231-6234.

Shimizu T, Yamashita A, Hayaishi O (1982) Specific binding of prostaglandin $D_{2}$ to rat brain synaptic membrane: occurrence, properties and distribution. J Biol Chem 257:13570-13575.

Sternberger LA (1979) Immunocytochemistry, pp 354. 2nd ed. New York: Wiley.

Taylor DCM, Pierau F-K (1991) Cellular neurophysiology. In: Studies in neuroscience: nociceptive afferent neurones (Winlow W eds), pp 36-49. New York: Manchester UP.

Uda R, Horiguchi S, Ito S, Hyodo M, Hayaishi O (1990) Nociceptive effects induced by intrathecal administration of prostaglandin $D_{2}, E_{2}$ or $\mathrm{F}_{2 \alpha}$ to conscious mice. Brain Res 510:26-32.

Ujihara M, Urade Y, Eguchi N, Hayashi H, Ikai K, Hayaishi O (1988a) Prostaglandin $\mathrm{D}_{2}$ formation and characterization of its syntheses in various tissues of adult rats. Arch Biochem Biophys 260:521-531.

Ujihara M, Tsuchida S, Satoh K, Sato K, Urade Y (1988b) Biochem- 
ical and immunological demonstration of prostaglandin $D_{2}, E_{2}$ and F $2 \alpha$ formation from prostaglandin $\mathrm{H}_{2}$ by various rat glutathione S-transferase isozymes. Arch Biochem Biophys 264:428-437.

Ujihara M, Horiguchi Y, Ikai K, Urade Y (1988c) Characterization and distribution of prostaglandin $D$ synthetase in rat skin. $J$ Invest Dermatol 90:448-451.

Urade Y, Fujimoto N, Hayaishi O (1985) Purification and characterization of rat brain prostaglandin D synthase. J Biol Chem 260:1241012415.

Urade Y, Fujimoto N, Ujihara M, Hayaishi O (1987a) Biochemical and immunological characterization of rat spleen prostaglandin D synthase. I Biol Chem 262:3820-3825.

Úrade Y, Fujimoto N, Kaneko T, Konishi A, Mizuno N, Hayaishi O (1987b) Postnatal changes in the localization of prostaglandin D synthase from neurons to oligodendrocytes in the rat brain. J Biol Chem 262:15132-15136.

Urade Y, Nagata A, Suzuki Y, Fujii Y, Hayaishi O (1989a) Primary structure of rat brain prostaglandin D synthetase deduced from cDNA sequence. J Biol Chem 264:1041-1045.

Urade Y, Ujihara M, Horiguchi Y, Ikai K, Hayaishi O (1989b) The major source of endogenous prostaglandin $D_{2}$ production is likely antigen-presenting cells. Localization of glutathione-requiring prostaglandin D synthetase in histiocytes, dendritic and Kupffer cells in various rat tissues. J Immunol 143:2982-2989.

Urade Y, Ujihara M, Horiguchi Y, Igarashi M, Nagata A, Ikai K, Hay- aishi O (1990a) Mast cells contain spleen-type prostaglandin D synthetase. J Biol Chem 265:371-375.

Urade Y, Watanabe K, Eguchi N, Fujii Y, Hayaishi O (1990b) $9 \alpha$, $11 \beta$-Prostaglandin $\Gamma_{2}$ formation in various bovine tissues. Different isozymes of prostaglandin $D_{2} 11$-ketoreductase, contribution of prostaglandin $F$ synthetase and its cellular localization. J Biol Chem 265: 12029-12035.

Urade Y, Kitahama K, Ohishi H, Kaneko T, Mizuno N, Hayaishi O (1993) Dominant expression of $m R N A$ for prostaglandin $D$ synthase in leptomeninges, choroid plexus, and oligodendrocytes of the adult rat brain. Proc Natl Acad Sci USA 90:9070-9074.

Vasko MR, Crider J, Campbell W (1989) Prostaglandins increase the release of substance $P$ from cultured sensory neurons. Soc Neurosci Abstr 15:471.

Vesin M-F, Droz B (1991) Biosynthesis of prostaglandins $D_{2}$ and $E_{2}$ in chick dorsal root ganglion during development. J Neurochem 57: 161-166.

Vesin M-F, Barakat-Walter I, Droz B (1991) Preferential synthesis of prostaglandin $D_{2}$ by neurons and prostaglandin $E_{2}$ by fibroblasts and non neuronal cells in chick dorsal root ganglia. J Neurochem 57:167174.

Wolfe LS, Rostworowski K, Pellerin L, Sherwin A (1989) Metabolism of prostaglandin $D_{2}$ by human cerebral cortex into $9 \alpha, 11 \beta$-prostaglandin $F_{2}$ by an active NADPH-dependent 11-ketoreductase. J Neurochem 53:64-70. 